УдК 341.1

\author{
B. О. Глушков
}

\title{
МНОГОПОЛЯРНЫЙ НОВЫЙ МИРОВОЙ ПОРЯДОК ПРОТИВ МОНОПОЛЯРНОГО МИРА (В РАЗРЕЗЕ РАСКОЛА ЭЛИТЫ ЗАПАДА)
}

Современная планетарная ситуация отличается многогранностью экономических и политических проблем, обусловленных общим кризисом капитализма, решение которых и их последствия имеют непосредственное отношение к коренным изменениям геополитической ситуации в мире. K краеугольным проблемам такого уровня относится проведение в июле 2016 года референдума в Великобритании относительно ее дальнейшего пребывания в членстве Евросоюза (Brexit) и проведение в ноябре этого же года выборов в США. Эти события тесно связаны между собой и взаимообуславливают друг друга. Дональд Трамп оригинально сравнил гонку в США с компанией «Брексит»: сегодня «Брексит»- завтра победа Трампа.

Следует отметить, что до проведения референдума Великобритания прошла длительный, сложный и противоречивый путь, приведший страну к сакраментальному решению о выходе страны из Европейского союза. Результаты референдума не являются какой-то неожиданностью для британских политиков, но значение такого политико-правового факта выходит далеко за пределы самой Англии, Европы, а также это имеет серьезные геополитические последствия для всего мира. Голоса лиц, принимавших участие в референдуме, разделились следующим образом: $52 \%$ из них проголосовали за выход из Евросоюза, причем большую часть из них представляло сельское население, а 48\% - это крупные города, которые захотели остаться в Евросоюзе. Естественно, что многих заинтересованных находящихся в различных цивилизациях планеты лиц интересуют причины и последствия такого геополитического шага Великобритании.

Следует особо подчеркнуть, что причины такого подхода Англии к членству в Евросоюзе имеют внутренний и внешний (то есть комплексный) характер, и последствия референдума будут ощущаться в политической жизни планеты длительный период. Сравнить можно только с развалом 
СССР: его (референдума) результаты будут чувствоваться в мире как распад СССР, и не только в постсоветском пространстве.

Закат Европы начался давно. Первая и Вторая мировые войны, холодная война покончили с гегемонией Европы в мире, то есть европоцентризмом, возникшим еще в период ее бурного расцвета. Это причины экономического современного тупика, в котором находится мировая экономическая система, которая была задумана Соединенными Штатами Америки еще около ста лет назад. За этот период Европа шла от кризиса к кризису, а внутренние проблемы Англии и внутренние проблемы Европы значительно переплетались. Они рождались уже в идее создания единой Европы, реализация которой проводилась без учета особенностей исторического развития каждой страны. Этот процесс интенсифицировался распадом Советского Союза, разграблением Западной Европой Восточной, что позволило укрепить западноевропейскую экономику.

В современных условиях экономическая ситуация уже сложилась по-другому: Западная Европа из субъекта могла превратиться в объект экономической экспансии в результате создания Трансатлантического экономического сообщества, которое бы дало возможность США сохранить свою экономику за счет ослабления и подчинения экономики себе Западной Европы и сохранения ослабленного состояния Евросоюза. Евросоюз задумывался как объединение экономик шести развитых европейских государств. Со временем эта европейская организация стала перерастать в совершенно другое образование, что проявилось в расширении Европы больше по политическим мотивам, а не экономическим основаниям. В количественном аспекте Евросоюз стал состоять из 28 государств. Он оказался больным теми же болезнями, которыми страдают и другие государства. Особо важное значение имеет уровень управленческой проблемы, которая заключается в том, что европейская бюрократия обладает примитивным пониманием происходящих глубинных процессов в Европе, неспособностью принимать оптимальное решение. Это связано с тем, что в настоящее время ведущие посты в европейской бюрократии занимают люди, которые, будучи еще студентами в 1968 году в период студенческой революции, выгоняли профессуру из высших учебных заведений, но сегодня ее некоторые участники сами стали профессурой, а некоторые также стали занимать ведущие места в управленческом аппарата Евросоюза и отдельных стран.

Евросоюз может сохраниться только в том случае, если будет единая законодательная, финансовая и экономическая системы, что может вести к созданию единого надевропейского правительства, что, собственно, и начала осуществлять европейская бюрократия в Брюсселе под силовым давлением Германии, Франции. Однако уже сейчас оказалось невозможным создание единой законодательной системы в связи с особенностями законодательства каждой европейской страны. Европа не смогла справиться ни с одной сложной проблемой. В частности, наиболее ярко проявилась экономическая проблема Греции. В этом плане также проблематич- 
ными являются Италия, Испания, Португалия, Франция, не говоря уже о восточно-европейских странах, фактически являющихся иждивенцами, а также стран, рвущихся в члены Евросоюза (Грузия, Украина, Молдова и особо Турция). Другие страны члены Евросоюза находятся в довольно сложном положении, кроме Чехии, которая экономически связана с Германией и справляется со своими проблемами. Таким образом, можно выделить наиболее сильные самостоятельные страны - Германия, Австрия, Чехия и Венгрия, то есть страны бывшей Германской и Австро-Венгерской империй.

Еще одна сложная проблема, которую так и не смогла решить европейская бюрократия, - это миграционный кризис, сопровождающийся грабежами и изнасилованиями. Следует отметить хорошо спланированную акцию, которая, с одной стороны, должна опустить рейтинг существующих лидеров, а с другой - выявить лидеров, которые проведут Европу в Трансатлантическое экономическое сообщество. Возникла и существует проблема пришедших более миллиона мусульманских и арабских беженцев с Ближнего Востока по решению «султана» Турции. Плюс заполнение Единого экономического пространства иностранными рабочими: так, Британию наводнили мусульманские, арабские, польские работники, литовцы - Ирландию. Фактически ведущие страны (Германия, Франция) находятся под протекторатом США.

Меркель - это несамостоятельный политик. Попытка США овладеть европейской экономикой за счет трансатлантического пакта оказалась той каплей, которая переполнила чашу терпения населения Европы. Британия была самым сильным проводником политики США. Свою позицию, отличную от США, заняли Виндзоры, Ротшильды, часть германской, северо-итальянской аристократии. Крупные европейские корпорации не хотят, чтобы их поглотили. Евросоюз постепенно вошел в глубокий кризис, который еще углубился с принятием стран Восточной Европы, что создало для него серьезные экономические и политические проблемы. Миграционные процессы в Европе являются хорошо продуманными и организованными социоинженерными операциями со стороны англосаксов. Проблему беженцев Брюссель оказался не в состоянии решить, и управление Евросоюза пришло в кризис. Необоснованное и непродуманное вмешательство в события в Украине только усложнило решение ее проблем. Новая Европа оказалась значительно слабее старой. Общеевропейские проблемы остались, поэтому должны быть проведены новые реформы.

Кроме того, нужно отметить и такой историко-политический факт: евроинтеграция всегда находилась в пропорциональной зависимости от развития евразийских процессов. После возникновения российской империи со времен Петра I восстановление единой Европы становится проблематичным и наоборот. Произошедшие в Европе террористические акты показали неготовность силовых структур противостоять террористической агрессии. Кроме того, в европейском обществе наблюдается определенная инфантильность самого населения, живущего в условиях дехристианиза- 
ции, разгула гомофилии, гомобраков, а также существования домов для зоофилов и т. п., что свидетельствует об определенной духовной кастрации людей. И этому обществу фактически противостоит молодое и агрессивное начало мусульманской миграции.

Назревшие проблемы требовали разрешения, и многие политики видели выход из создавшейся ситуации в разрушении Евросоюза. Все это сломило Британию, и самая сильная демократическая страна не захотела подчиняться плутократии Брюсселя.

Естественно, что экономика Британия сохранит отношения с Европой, но в новой форме: она не будет больше участвовать в решении проблем европейского сообщества. В случае установления взаимоприемлемых взаимоотношений с Европой усилится тенденция ухода из Евросоюза и других стран. Кандидатом на выход может быть такая сильная в экономическом отношении страна, как Нидерланды, граждане которых также полагают, что они могут иметь с Европой свои особенные отношения и самостоятельно, без указки Брюсселя решать свои проблемы. Такой вопрос стоит также и перед Данией. Никто не смог ответить британской королеве на ее вопрос о трех причинах, по которым они должны остаться в Европе. Ответ дали сами англичане.

Следующая проблема. Ослабленная Европа приведет к невозможности содержать страны-иждивенцы - Болгарию, Румынию, страны Прибалтики. Евросоюз покидают или сильные, или слабые страны. Покинуть Евросоюз может Венгрия, она является сильным государством, сохранившим свою экономику. Останутся или чрезвычайно сильные, или слабые. Такое сильное государство, как Германия, останется, ибо выход Британии пошел на пользу Германии. Лондон перестанет быть финансовым центром мира, а Франкфурт уже готовится стать центром финансовым центром Европы. Таким же центром в Европе готов стать и Париж. В целом открывается тенденция создания нескольких финансовых центров, таких как, в частности, Шанхай, Гонконг. Становление и усиление Германии как финансового центра мира будет серьезной поддержкой для германской экономики. Это значительно усилит Германию. Франция также не приходит в восторг от трансатлантического партнерства. Европе без Британии сложно общий язык с тем, что находится восточнее, - Россия, Китай, Дальний Восток. Этим странам легче развивать экономические отношения порознь с каждой страной. То есть это то, чему препятствовали США. Естественно, произойдет пересмотр взаимоотношений между США и Великобританией. У кандидатов в Евросоюз шансы вступления невелики. Европа не будет заниматься присоединением новых стран - Молдавии, Украины, Грузии и Турции. Новая Европа вряд ли будет их кормить. Начинается новый мир, и последствия - планетарного масштаба.

В новых условиях становится вопрос о реорганизации Евросоюза. Сегодня наблюдается деградация уровня политических деятелей, которые управляют в Европе. Нынешнее политическое управление не соответствует опасности, которая имеет место в Германии Франции и других странах. 
Одна из таких опасностей - террористическая. Количество терактов будет увеличиваться, если не будет сильного противостояния со стороны адекватного правительства, способного не допустить беспомощного состояния, которое было проявлено со стороны бельгийцев, французов и немцев.

Один из путей реорганизации Евросоюза - создание мощного единого государства. В этом плане следует сказать, что в ЕС имеется противоречие между равноправным членством и доминированием Германии при содействии Франции и стран Бенилюкса. Естественно, Германия не захочет терять своих передовых позиций, поэтому власть в Евросоюзе постепенно перейдет к Германии при содействии Франции (т. н. Четвертый рейх). Осуществится максимальная политическая централизация Евросоюза. Все решения будут формироваться в Берлине и выполняться всеми остальными. Возможно возникновение политического франко-германского союза, которого никогда не было в истории. Такой союз с неизбежностью будет поддержан Россией, и он будет осуществляться через голову Польшу, которая сегодня служит оппонентом Германии. В этом плане возможен и пересмотр границ Польши - как на западе, так и на востоке. Поляки готовы занять место Великобритании в Евросоюзе. Для американцев переформатирование Европы не является критическим, они согласятся с любым вариантом, который не будет для них опасен. Для Германии же вопрос доминирования - это и вопрос выживания. Поэтому для защиты своих интересов Германия может применять любые меры и средства.

Другой путь - путь децентрализации. Децентрализация связана с ликвидацией евро и введением национальной валюты. Эта проблема также имеет и другую сторону относительно более слабых европейских стран, которые находятся на грани распада: это Испания с Каталонией и басками, Италия, в которой сильны тенденции раздела страны на две по линии Север - Юг. И если Шотландия отделится от Великобритании, то станет взрывоопасным стимулятором. В таком случае в таких странах, как Италия и Испания, теряется единый государственный механизм. Евросоюз не в состоянии решить проблемы этих стран.

Сторонниками сохранения членства Великобритании по проведению референдума в Шотландии, с точки зрения агитации, было вынесено два урока. Шотландцев запугали страхом неизвестности, выстроили свою кампанию на запугивании и на идее экономики. Запугивание не сработало. Аргументы были недостаточно точными: например, то, что будут обрушены финансовые рынки, простых людей совершенно не интересовало. Разделение проходило по линии «начальники - простые люди». Начальники выступали за сохранение членства, а простые люди - против. Агитация среди простых людей фактически не проходила. В этом плане показательна демонстрация, в которой флотилия рыбаков вышла на своих утлых суденышках, а высшее общество выехало на своих яхтах. Элита оскорбила простое население. Большая часть печатных СМИ в основном поддержали компанию за выход из ЕС. В референдуме приняли участие $72 \%$ британцев, при этом проголо- 
совало за сохранение членства $74 \%$ шотландцев, а в Северной Ирландии $56 \%$. Результат был неожиданный, что вызвало шок у обеих сторон.

Это одна сторона вопроса, заключающаяся в том, что отношение к вопросу выхода/невыхода проходит по линии «элита - простые люди». Вторая сторона проблемы заключается в том, что сама британская элита в данном вопросе разделилась и, как показал референдум, не занимает единой позиции. Однако рассмотрение вопроса о разделении британской элиты невозможно рассматривать без раскола элиты в западном мире. Исторически и традиционно британская элита делится на две группы: первая тяготеет к континентальной элите, а вторая - имперская независимая (т. н. Ротшильды). Именно к имперской элите был направлен полет заместителя Гитлера Рудольфа Гесса. Однако к власти пришел Черчилль, который в 1940 году сдал Англию Америке, разрешив торговать напрямую со странами-колониями, а взамен получил старые эсминцы для конвоя. Этим он разрушил империю. Британия потеряла свою колониальную мощь и вошла в подчинение к американцам. В ЕС Британия сохранила самостоятельность - валюта, визы.

В мировой элите можно четко выделить две линии: финансово-глобалистскую (в США представителем является Хилари Клинтон) и изоляционистскую региональную (в США - президент Дональд Трамп). За этими лидерами просматривается два направления в мировой и национальной финансовой политике: смягчение денежной политики и ее ужесточение. Оба эти процесса в целом негативны, но за счет различных сценариев: сильная девальвация в России, экономические проблемы в Китае, устройство оффшорных скандалов в Лондоне с последующим изъятием денег. Оффшоры это источники, которые не контролировали наднациональные круги, одна из причин выкачать деньги из Великобритании - 2,5-3 трлн. Лондон понял, что нужно переходить к другому направлению; иными словами, это попытка мировой финансовой системы сохранить свою власть и экономическое могущество. Другой путь заключается в попытке спасения экономики США за счет мировой системы. Это направление сегодня представляет Дональд Трамп, который, естественно, не является самостоятельной фигурой, но представляет мощную силу в американском истеблишменте, которая полагает наиболее целесообразным проведение политики изоляционизма, регионализации мира, ликвидации мировой глобальной финансовой системы для спасения американской экономики, а также проявляет нежелание спасения других стран за счет Америки. В настоящее время наблюдается процесс перехода многих политических сил Америки на сторону изоляционистов.

Дональд Трамп по специальности строитель, представитель реального сектора, не финансист, является левым радикалом, выступает в качестве защитника интересов народа. Для американского народа в реализации любого направления произойдет падение уровня, однако либо без шансов на улучшение (Клинтон), либо с шансами (Трамп). Трамп является принципиальным противником войны, которую может устроить Клинтон. Причинами этой войны являются неразрешимые экономические и финансовые 
проблемы. Для разрешения такой проблемы лучшим вариантом является серьезный военный конфликт.

Предвыборная кампания в США проходила в острой и непримиримой борьбе двух различных по геополитическим направлениям национальной и наднациональной элиты. Результат вроде бы предрешен, и американская политическая элита определилась. Трамп нею рассматривался как фигура, выгодная для Клинтон, в качестве американского Жириновского. Но Трамп уверенно выиграл в республиканской партии, не допустил ее раскола. В связи с этим резко изменился сценарий, и его надо было переписывать.

США вышли победителем в XX веке и оказались заложниками в продолжении своего глобального проекта. Половина мировых активов находится у $1 \%$ человечества. В настоящее время наблюдается общий кризис десяти процентов белого человечества, которое отвергло базовые постулаты христианства и заменило их либеральными ценностями. Кризис в США развивался постепенно и имеет объективные и субъективные причины. После президента Никсона Штаты постепенно сползали к ситуации, которая в современных условиях поставила под угрозу сам факт американского существования. США перешли к политике мирного сосуществования, взаимного учета интересов. Однако пришедший Рейган уже назвал СССР империей зла. В соотношение «Рейган - Горбачев» США поменяли свой вектор политики, с распадом СССР подошли к своей желаемой цели - Рах Americana - и стали понемногу управлять миром.

Эта политика увенчалась бы успехом, если бы она продолжалась и в XXI веке. Однако возникли новые элементы, которые не входили в планы Штатов, новые мировые центры - Китай, Россия, Индия ЮАР, Бразилия. Тогда в США возникла идеология сохранения существующего порядка. Однако такая политика глобализации и образования наднациональных структур стала непосильной для США, это проявилось во внешнем перенапряжении, в военном плане они шли от поражения к поражению и сами стали жертвой. Это приводило к возрастанию государственного долга в стране, и внутренние процессы пришли в дополнение к внешним.

В этот период в США сложилась сложнейшая политико-экономическая ситуация, заключающаяся в том, что народ страны устал от предсказуемости, ибо демократия вошла в глубокий структурный кризис, когда вся она сводилась к тому, кто из семейства Бушей или Клинтонов будет решать, как будет жить страна ближайшие сто лет. Требовалось оптимальное разрешение ситуации при условии сохранения самой системы демократии. Нужен был непредсказуемый человек. Две тенденции сошлись на этих выборах - консервативный модерн и либеральный глобализм. Представителем последнего была Хиллари Клинтон, которая находилась в фарватере наднациональных финансовых структур, полагавших хаос на периферии и постмодернизм в ядре, это могло привести к перенапряжению страны, она могла рухнуть, как СССР. Консерваторы-модернисты предлагают реализацию стратегии порядка. Нужен был новый и особенный человек. 
В стане демократов таким был Сандерс, выдвинувший фактически социалистические лозунги относительно внутренних изменений в США, народ поддержал его, но правящий бюрократический аппарат партии недемократическим путем привел к власти кандидата Хиллари Клинтон вопреки желаниям членов партии.

Выборы показали проблемы более глубокие, чем бюрократические перестановки, США вошли в тупик внешней и внутренней политики, и политический кризис в США достиг апогея. Экономика Штатов стала спекулятивной еще в двадцатые годы прошлого столетия, они стали единственной мировой державой, которая стала приписывать всему миру, как жить. Перед Америкой встал вопрос о будущем и прошлым. Именно здесь возникло соперничество. Американцы хотели видеть новую Америку с истинными государственными интересами, изменить ее внешнюю и внутреннюю политику, методы управления страной и экономикой, приспособить государственные институты к сложившейся ситуации, рассчитаться с долгами и занять равное место среди других стран. У Соединенных Штатов еще есть возможность эволюционно провести реформирование страны, не доведя ее до потрясения, какое было после вьетнамской войны. Население страны хотело вернуться к естественному пути развитию. Этой цели соответствовал Дональд Трамп, но не Хиллари Клинтон, которая не смогла бы сделать это эволюционно.

Фон предвыборной кампании создавали СМИ. Все американские и европейские медиа в один голос утверждали, что кандидат от Республиканской партии является представителем маргинальных слоев населения и его поддерживает Кремль. Вся социологическая служба США оказалась несвободной, управляемой, их материалы согласовывались с представителями штаба Клинтон. Население убеждали, что Трамп не сможет одержать победу, с трудом может набрать максимум $30 \%$ и т. д. В конечном счете налицо провал всей социологической службы, объективной деятельности СМИ.

Во время предвыборной кампании одной из технологий, широко применявшихся против Трампа, было его очернение, во время которого использовались непотребные высказывания и действия в отношении женщин, а другой - антироссийская пропаганда и подведение Трампа под агента Кремля. Когда антироссийская риторика Клинтон не сыграла роли, то в ход против Трампа была запущена тяжелая артиллерия, что привело к обратному результату. Национальный комитет демократической партии пытался скомпрометировать Трампа, рассматривая его не только как агента Кремля, но и даже как «полезного идиота Путина». Однако и это к нему не пристало, и американский избиратель отбросил эту дезинформацию. Однако политтехнологи допустили ошибку и недооценили народ США, что в целом привело к росту уважения к Трампу. K Трампу и к Сандерсу народ валил на встречу, а к Хиллари народ свозили. Наблюдатели в целом отмечали необычно высокую явку на выборы.

Население США не интересуется внешней политикой, так как полагает, что внешнеполитические проблемы являются только обузой для США. 
Этот момент был использован Трампом, выдвинувшим идею возвращения народу, который создал Америку, своих ценностей, а не поддержки раздутых финансовых спекулятивных корпораций, которые не создавали американскую экономику. На Хилари работали нефтяные короли, которые создали капитал за границей. Таким образом, в самом центре капитализма началась революция в верхушке мирового капиталистического класса. При этом Трамп является меньшим злом, чем Клинтон, ибо с ней Америка очень близко подошла к опасной черте в мировой политике, а при Трампе эта черта отодвинулась. Семейство Клинтонов очень заинтересовалось мусульманской религией, что не может быть поддержано Трампом. Клинтоны поддержали радикальный ислам, тогда как Трамп не будет делать ставку на такой ислам.

США в XXI веке в современном мире не имеют ни возможности, ни желания управлять миром, так как они занимают несоответствующее, раздутое еще в XX веке место. Им необходимо вернуться к естественным размерам, вернуть Америку американцам, ибо у нее нет своих национальных интересов ни в Украине, ни на Ближнем Востоке, ни в Южнокитайском море, а они находятся на территории от Атлантического до Тихого океана; возвратиться к состоянию, которое было 100 лет назад, и перестать быть мировым жандармом и навязывать миру свои правила жизни. Как к этому прийти: либо путем катастрофы, либо избрать более цивилизационный путь, не прибегая к революции и достигая цели малой кровью? Необходимо использовать свои здоровые экономические возможности, не подкрепляя их военными и политическими авантюрами и не являясь мировым жандармом. Однополярный мир кончился, и миру не нужен жандарм, ибо сами страны справятся с проблемами, которые будут возникать. И ни одно государство не должно предписывать другим, как жить. По мере возвращения государств к естественным границам патронистский контроль становится ненужным.

Выбор американского народа является событием исторического масштаба. Это победа среднего класса, который работает, содержит нахлебников внутри страны и за ее пределами, в условиях ускоренной глобализации стал жертвой ускоренной глобализации и потерял связь с национальной элитой. Были поставлены под сомнение базовые ценности последних десятилетий, ценности мультикультурализма и глобализации, необходимость оптимизации темы борьбы с терроризмом, миграционных процессов, особенно миграции мусульман, поэтому народ поверил и проголосовал. Им высказана необходимость постройки стены между Мексикой и США, оптимизации торговли с Китаем, он подверг критике тихоокеанское торговое сообщество, выступил против избыточного военного присутствия США за пределами страны, поддержал идею создания рабочих мест внутри страны. И поэтому Трамп, трижды обанкротившийся и трижды вставший, ближе к среднему классу, который не нашел своего места в модели культурализма и глобализации, к мелкому и среднему предпринимателю, нежели Клинтон. Он из реальной жизни и лучше знает, что нужно американскому 
избирателю. Фактически он только начал политическую карьеру, за ним не стоит партия или блоки. За него голосовали американцы из глубинки, ржавый пояс Америки. Впервые за 240 лет народ взял судьбу страны в свои руки согласно Конституции США. Главный итог выборов - колоссальный раскол американского общества, оказывающего влияние на весь мир, и то, что политическая элита страны поняла, что народ ее не поддерживает.

Блестящая победа Трампа, которая имеет колоссальное значение и для всего мира, вызвала волнение, поддержку и создала противников во всем мире. Выросло новое поколение работающих американцев, и они не хотят диктата со стороны правящей элиты, это глубинка Америки и ее репрезентативный возраст - 45-60 лет. По количеству голосов Клинтон превысила Трампа почти на миллион, но выборщики решили вопрос в пользу Трампа.

В современных условиях Западная Европа лишена международно-правовой мировой правосубъектности, и ее верхушка симпатизировала Клинтон. Европейские элиты поддерживают продолжение санкций против России, но санкционный пресс со стороны США должен закончиться, и возникнет необходимость решать этот вопрос уже в марте 2017 года, когда закончится срок санкций, которые установлены Обамой. В то же время намечается ренессанс российско-американских политических и экономических отношений, создание оси Вашингтон - Москва. В этих условиях будет конструктивно обсуждаться проблема Крыма, Донецка, Луганска, применение санкций и т. д.

Одна из самых больших проблем в международной политике - это проблема решения вопросов по сирийскому конфликту. Эта проблема может стать первой темой для реального совместного конструктивного сотрудничества США и России. Ибо у Трампа совсем иная точка зрения в отношении модели нового мирового порядка. Главное - обеспечение безопасности внутри США. Американский народ не хочет оплачивать мировой либеральный беспорядок, но в то же время, несмотря на провозглашаемую политику изоляционизма, он не отказывается от мирового лидерства и мирового господства, что в конечном итоге создает конфликт. И в этом плане особое место занимают проблемы Сирии. Здесь столкнулись политика глобализма и политика национальных государств, где США поддерживают политику халифатизма. Но в то же самое время США не смогли провести разграничение между т. н. умеренной оппозицией и террористами. Весь Ирак в крови, Афганистан, Вьетнам, страны Ближнего Востока, сложная ситуация вокруг Алеппо, Мосула, Ракки - все это ставит проблему активизации борьбы с экстремизмом и тероризмом на первый план в XXI веке. Трампом сделано важное заявление о необходимости совместного с Москвой уничтожения Исламского государства.

Трампу безразлично, сколько региональные державы Ближнего востока - Садовская Аравия и Катар - вложили денежных средств в разжигание и поддержание этого конфликта. Но Америка не может так просто уйти из Сирии и отдать России экономическую сторону восстановления 
Сирии после конфликта. Мир стремительно меняется. В США намечается перекачка ресурсов и запуск собственной экономики, а не ее развал, Сирию надо воссоздавать более активно. Поэтому Сирию должны отстроить сирийцы, а Ирак - иракцы. Тут необходимо плодотворное международное сотрудничество.

Главным неудачником выборов является Украина. Ее ориентация на страны Запада и Прибалтики, ошибочно поддержавших Клинтон и полагавших, что они могут работать с любым президентом, показала неспособность их профессионального прогнозирования и понимания качественного изменения самой Америки. Отдельные представители Украины вложили серьезные средства в фонд Клинтонов и тем самым проиграли, не поняв, что политика может измениться в невыгодном для них направлении. У американцев нет интересов в Украине, они заинтересованы в создании в этой стране легитимной демократической власти с нейтральным внеблоковым станом, миролюбивыми отношениями с Россией, в Украине, нашедшей свое истинное место в межгосударственных союзах. При этом Трамп обещал рассмотреть вопрос о встрече с Президентом РФ В. Путиным в Крыму до инаугурации. Он верит в хорошие отношения с Россией. Трамп заявил, что народ Крыма хотел бы быть с Россией, а не там, где они были прежде, и это тоже надо рассмотреть. Что касается Украины, то она в беспорядке. Крым забрали, и нельзя обвинять в этом Дональда Трампа, Попытки со стороны США отобрать силой Крым у России и возврат полуострова Украине может спровоцировать Третью мировую войну.

Трамп является продолжателем традиций Рональда Рейгана, у которого не получилась внутриполитическая политика, натолкнувшись на серьезную оппозицию, и поэтому он стал бороться с империей зла, то есть Советским Союзом. Трамп же полагает, что он сделает то, что не удалось Рейгану, и сосредоточится на внутренних проблемах. Рейган сформировал вашингтонский консенсус, обеспечил рост экономики. Трамп апеллировал к душе американцев, подхватив идею Франклина Рузвельта о забытом человеке. И «клетчатые рубашки» голосовали за него. Трамп победил в выборах не один и имеет неразделенное правление, так как обе палаты состоят из республиканцев.

Судя по всему, президентство Трампа приведет всю систему международных отношений к потрясению тектонического масштаба, появятся новые возможности отношений с другими странами, не будет продолжения конфронтационного курса. Особое внимание будет уделено западноевропейским странам, где будут проходить выборы и правые приходят к власти, меняется идентичность западноевропейского общества. Как политический реалист он будет по-иному формулировать американские интересы, которые будет жестко отстаивать, полагая, что Китай - это угроза национальным интересам США, Россия бросила вызов либеральному порядку. Он пойдет на срыв иранской ядерной сделки, в чем его поддержит Израиль, он изменит американскую политику в Афганистане. Он пересмотрит отношения с Саудовской Аравией, Катаром, Ближним 
Востоком, при этом особое внимание уделит зеленой угрозе исламского терроризма.

Мир фундаментально изменился и перестал развиваться по американскому сценарию. Претензия на мировое лидерство отвергается и начинает работать против самой Америки. Трамп является симптомом и результатом этого кризиса человечества. Элита завела мир в тупик, и Америке надо отступить, а простому человеку такая ситуация надоела.

Как будет он взаимодействовать с истеблишментом (а Вашингтон не знает, что будет делать Трамп)? Особые отношения у Трампа сложились с силовой составляющей американского общества. Если армия и ВПК его поддержали, то со специальными службами отношения не сложились, они относились к нему скептически. Ими даны ошибочные суждения об Ираке, Украине, 11 сентября 2011 года. Поэтому в системе безопасности предстоят серьезные реформирования и кадровые изменения, и силовики будут под него подстраиваться. Преобразования также ожидают финансовую систему, где Трамп полагает возвращение к национальным основам. Трамп - это старые деньги. Трамп - сам представитель истеблишмента, и он должен сблизиться с его ключевыми фигурами, должно наблюдаться взаимное движение. Раскол в Америке привел тому, что существуют целые города (Вашингтон на 93\% проголосовал против Трампа), которые проголосовали против Трампа, неоконы ушли и примкнули к демократам, но пришли консерваторы. Он пришел на свои деньги. И сложно политически определить: или это традиционалистская революция (контрреволюция), когда общество возвращается к естественному ходу вещей, или консервативная контрреволюция. Скорее, и то и другое - консервативная традиционалистская революция. Но в любом случае наблюдаются коренные изменения в высших слоях западной элиты. Ясно и другое. С момента выборов закончился монополярный мировой порядок, и его место занял многополярный новый мировой порядок.

Феномен Трампа является последствием глобализации, которая дестабилизировала весь мир, и вся зараза хлынула в Америку из Мексики, образовался поток терроризма, прошли арабские революции, элиты увидели возможность делать деньги за пределами страны в офшорах, достижения хлынули за пределы Америки, возник социальный конфликт между высшими и низшими слоями населения. В этом плане следует отметить, что и радикальный ислам - это ответ на ценности открытого мира. В США ничего не произошло, ибо Трамп - это кровь от крови представитель американского общества, он является олицетворением коренной Америки и капитализма в протестантском рае. И избиратели избрали американский образ жизни. Американские ценности как были, так и останутся. Трамп это возвращение классической американской мечты.

Победа провозглашенной Трампом политики регионализации будет способствовать возникновению таких самостоятельных регионов, как Британия, Германия, Россия, Китай, Индия, Бразилия, которые будут лидерами регионов в условиях многополярного нового мирового порядка. Доллар 
перестанет быть инвестиционным ресурсом. Его заменителем выступит региональная валюта. В экономических отношениях между Китаем и Россией уже предложено создать новую валюту - руань. Победа Трампа будет способствовать возрастанию роли России в своем регионе, в сферу которого может входить территория, которая больше, чем Российская империя. Если Берлин и Москва будут лидерами, то, естественно, между ними должна быть граница сфер влияния. Как она может быть проведена с учетом интересов обеих стран? Правее - Москва, левее - Берлин. Победа пророссийских сил в Молдове и Болгарии подчеркивает возрастание геополитического значения Российской Федерации.

Для народа США падение уровня жизни неизбежно либо без шансов на будущее (Клинтон), либо с шансом на таковое улучшение (Трамп). В Британии и в Германии к власти придут правые силы, при этом Лондон не захочет находиться под Берлином, поэтому, выйдя из Евросоюза, он фактически будет находиться под влиянием США. Во Франции возможен приход новых правых во главе с Мари Ли Пен. И Франция резко поправеет. Если Лондон посчитает целесообразным вести самостоятельную от США политику, то для этого ему необходимо осуществлять тесное взаимодействие с арабским суннитским миром. В этой связи понятно и усиление активности Тони Блэра на Ближнем Востоке и в арабском мире. В этом плане следует подчеркнуть, что мәром Лондона стал пакистанец.

В этот сценарий не вписывается Турция, которая под предводительством Эрдогана сама хочет быть региональным лидером и создавать свой халифат. В то же время Турцию суннитский мир не признает равноправным себе, а западный мир хочет отделить Турцию от суннитского мира и приблизить ее к России. Объединить суннитский мир можно только при наличии врага, и таковым может быть только Израиль. В этом плане интерес представляет высказывание Генри Киссинджера, который полагает, что к 2022 году Израиля больше не будет.

После проведения референдума риск распада Великобритании резко возрос. Шотландия более близка к континентальной Европе и обязательно вернется к идее референдума. Сложная ситуация также сложилась в Северной Ирландии. Фактически Британия может остаться в союзе с Уэльсом.

Россия начиная с времен Ельцина находилась в кризисной ситуации, которую претворила в жизнь команда финансистов Клинтона во главе с Лари Саммерсом из Гарвардского университета. В настоящее время ситуация в России довольно сложная: президентская команда - нелиберальная, а правительство - либеральное. Такая ситуация долго продолжаться не может. Нужна институциональная оппозиция, а не вождистские партии.

Силы изоляционистской части мировой элиты в Китае представляет изоляционист Си Цзи Пинь, во Франции - Мари Ли Пен, в Венгрии пришла к власти националистическая партия «Йобик» во главе премьер-министром Урбаном, роль которого в связи с выборными событиями в США значительно выросла. Результатом референдума в Британии является то, 
что постепенно поднимают голову патриотические силы, а не транснациональные партии финансистов. Эти же силы подняли Трампа. Евросоюз - это не жилец, он может существовать только при условии избытка финансового ресурса. Поэтому Восточную Европу просто выкинут из Евросоюза либо могут предъявить жесткие экономические требования и условия по бюджетам. На базе франко-германской валюты будет создан новый евро.

Следует отметить, что проблема вулкана Йеллоустоун (штат Вайоминг) стояла и в планах кандидатов в президенты США. И как ни странно, она имеет отношение и к Украине. Так, кандидат в президенты США от Демократической партии Хиллари Клинтон в своем интервью корреспонденту заявила, что США не могут игнорировать значительное ухудшение геофизической обстановки и разлома Сан-Андреас, ставящие под угрозой существование США. Вопрос стоит о переносе американской государственности. Времени, чтобы сохранить независимость и дальнейшее процветание США, осталось мало, а следовательно, необходимо более решительно и последовательно рассматривать вопрос о переносе американской государственности на европейскую территорию.

Основным вариантом такого переселения может рассматриваться территория Украины, климатические условия которой наиболее благоприятны для американских граждан, однако в силу стечения некоторых обстоятельств решение этого вопроса находится под угрозой срыва. Эта территория является наиболее благоприятной для глобального американского переезда и поэтому продолжится координация международного давления по возвращению Крыма в единое украинское территориальное пространство по состоянию на февраль 2014 года. Как к этому отнесутся Россия и Украина и как эту проблему намерен будет решать Дональд Трамп? Будущее покажет.

Таким образом, в настоящее время наблюдается смертельная схватка между национальными и наднациональными структурами, победа одной из них будет направлять развитие планеты на определенный период. Именно в США эти силы столкнулись в выборной кампании. В этом поединке решается проблема будущего мира, человечества, которое идет к многополярности нового мирового порядка, и он будет определять его дальнейшую судьбу.

\section{Анн н т а ци я}

Глушков В. О. Многополярный новый мировой порядок против монополярного мира (в разрезе раскола элиты Запада). - Статья.

Статья посвящена исследованию проблемы становления и эволюции геополитических процессов, способствующих реализации различных парадигм мироустройства современности. Анализируются особенности европейского дискурса нового мирового порядка, указываются их отличия от американской версии последнего. Затрагиваются вопросы трансформации механизмов развития и функционирования многополярного мирового порядка против монополярного мира. Автор анализирует проблему в разрезе раскола элиты Запада. мир.

Ключевые слова: мировой порядок, геополитическое противоборство, многополярный 


\section{Ано т а ц і я}

Глушков В. О. Багатополярний новий світовий порядок проти монополярного світу (у розрізі розколу еліти Заходу). - Стаття.

Стаття присвячена дослідженню проблеми становлення й еволюції геополітичних процесів, що сприяють реалізації різних парадигм світоустрою сучасності. Аналізуються особливості європейського дискурсу нового світового порядку, вказуються їхні відмінності від американської версії останнього. Порушуються питання трансформації механізмів розвитку та функціонування багатополярного світового порядку проти монополярного світу. Автор аналізує проблему в розрізі розколу еліти Заходу.

Ключові слова: світовий порядок, геополітичне протиборство, багатополярний світ.

\section{S u m m a r y}

Glushkov $V$. O. Multipolar new world order against unipolar world (by the splintering of Western elite). - Article.

Article is devoted to problems of formation and evolution of the geopolitical processes contributing to the realization of various paradigms of contemporary world order. The article analyzes the features of the European discourse of the new world order, indicating their differences from the American version of the latter. Raises issues of transformation of the mechanisms of development and operation of a multi-polar world order against the unipolar world. The author analyzes the problem in the context of a split West elite.

Key words: world order, geopolitical antagonism, multipolar world. 